\title{
Phenology of Migration and Decline in Colony Numbers and Crop Hosts of Giant Honeybee (Apis dorsata F.) in Semiarid Environment of Northwest India
}

\author{
Ram Chander Sihag \\ Laboratory of Animal Behaviour and Simulated Ecology, Department of Zoology, CCS Haryana Agricultural University, \\ Hisar 125004, India \\ Correspondence should be addressed to Ram Chander Sihag; sihagrc@rediffmail.com
}

Received 29 June 2014; Revised 31 October 2014; Accepted 3 November 2014; Published 2 December 2014

Academic Editor: Ignazio Floris

Copyright (C) 2014 Ram Chander Sihag. This is an open access article distributed under the Creative Commons Attribution License, which permits unrestricted use, distribution, and reproduction in any medium, provided the original work is properly cited.

\begin{abstract}
The colonies of the giant honeybee (Apis dorsata) immigrate in the semiarid environment of Northwest India in October-November with the onset of flowering on pigeon pea (Cajanus cajan)/toria (Brassica campestris var. toria), stay here during the rich pollen and nectar flow period from December to mid-May, and emigrate in late May/early June when floral dearth is witnessed. This honeybee was free from any conspicuous viral, bacterial, and fungal diseases and also did not have any serious predators and enemies. However, about 20 percent of the old colonies were infested with Tropilaelaps clareae and 100 percent of the old colonies with Galleria mellonella; none of the swarm colonies had these pests. While the migration schedule of this honeybee remained similar year after year, the number of colonies immigrating in this region declined markedly over the years; the number in 2012 was even less than half of that recorded in 1984. During its stay in this region, this honeybee acted as an important pollinator of more than 30 crop plants of this region. The causes of seasonal migration and decline in the number of colonies of this honeybee and its importance in crop pollination have been discussed.
\end{abstract}

\section{Introduction}

The giant honeybee (Apis dorsata F.) is a wild species indigenous to Pakistan, South Asia, and Southeast Asia [1] (Figure 1). This honeybee has a migratory habit; the colonies make seasonal migration. For the utilization of this honeybee as a pollinator and honey gatherer; knowledge about its seasonal migration schedules is important. Some earlier researchers studied the latter ecological phenomenon of the giant honeybee in the tropical climates of South and Southeast Asia [2-7]. The reports reveal that seasonal migration in this honeybee varied from place to place depending on the local climatic and floral conditions. In Sri Lanka, this honeybee had a regular annual cycle of migration [2]. In February, the colonies spread throughout the coastal plains and the North Central Region. In June and July, they migrated to the Up Country, which they left again in October-November. In Bangalore (India), this honeybee showed short and long distance migrations [3]. Short distance migrations seemed to be the local absconding occurred in response to internal disturbances in the colonies. The long distance migrations were the real migrations occurred due to floral dearth and inclement climatic conditions of the area [3]. Woyke et al. [4] too reported that swarms of the giant honeybee did not migrate directly to the seasonal alternative nesting sites but established new colonies in the areas around. After environmental conditions deteriorated, all the bees with their queens absconded and migrated to alternate seasonal nesting sites. In the Chitwan district of Nepal too, the giant honeybee showed seasonal migration $[5,6]$; the mean number of colonies declined steadily from May to August. There was no colony in September and October, got the highest peak in January, and started again declining from March onward [6]. In a rain forest habitat in Northeastern Thailand, migration of the giant honeybee allowed colonies to track seasonally varying floral resources in different regions [7]. Colonies arrived in the area during the end of the dry season, reproduced, and then departed early in the rainy season. During the immigration phase, early-arriving colonies stayed only temporarily, as if assessing habitat quality. Colonies which 


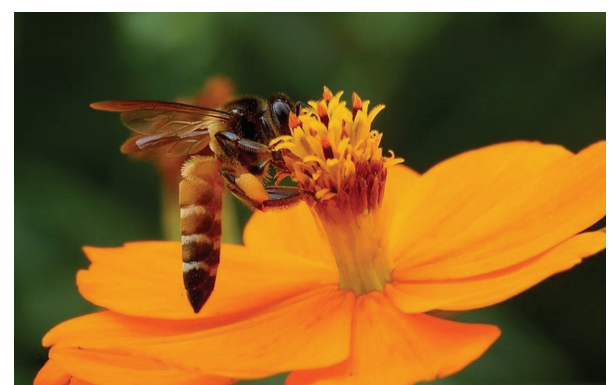

Figure 1: Apis dorsata foraging on a composite flower (Photo: Corona apicultores).

departed after a long stay always left barren combs behind. This indicated that the latter colonies had emigrated because of deteriorating resource quality [7]. However, conditions in the tropics, subtropics, and arid regions are different, and generalization of one region cannot be applied in another region. Therefore, knowledge about the migration schedule of this honeybee for the semiarid environment of Northwestern region of India is important to explore its potential as a pollinator of crops.

The giant honeybee has been reported as an important wild pollinator of both wild and crop plants [8]. Mann and Singh [9] and Sihag [10-12] also reported this honeybee as a promising pollinator of some horticultural and field crops of India. Recent reports reveal that both abundance and diversity of wild bees are now declining and some species are clearly at risk. Studies made in Britain and The Netherlands revealed evidence of decline in local bee diversity in both countries [13]. Depending on the assemblage and location, pollinator declines were most frequent in habitat and flower specialists, in univoltine species, and/or in nonmigrants. In conjunction with this evidence, outcrossing plant species that are reliant on the declining pollinators have themselves declined relative to other plant species. Taken together, these findings strongly suggested a causal connection between local extinctions of functionally linked plant and pollinator species [13]. It is anticipated that pollinator declines can result in loss of pollination services which have important negative ecological and economic impacts that could significantly affect the maintenance of wild plant diversity, wider ecosystem stability, crop production, food security, and human welfare [14]. However, status on the number of giant honeybee colonies in this region over the years is not known. This information on the giant honeybee is important to guide the conservation strategy of this honeybee for its utilization as a potential pollinator of crops and wild plants.

Floral dearth leading to scarcity of bee forage caused by the prevailing high temperature and drought condition and incidence of diseases, pests, predators, and enemies of the giant honeybee in a region could be the potential causes of its seasonal migrations. Earlier reports revealed that May to early July in Northwest region of India witnessed a very high temperature in the range of $43-48^{\circ} \mathrm{C}$ and June to midSeptember represented a period of floral dearth $[15,16]$. Earlier reports also revealed that the colonies of this honeybee were infested with wax moth (Galleria mellonella L.) [17] and an ectoparasitic mite (Tropilaelaps clareae Delfinado \& Baker) [18]. However, the intensity of damage caused to the colonies by these pests is not known. Likewise, information on other diseases and enemies of this honeybee is also not available.

In such regions of Asia, where Apis cerana F. is not indigenous and Apis mellifera L. has not yet been introduced and established, managed pollination is not practiced. In these regions, crop growers have to rely on the wild pollinators for pollination of their crops. Two species of Asiatic honeybees (namely, the dwarf honeybee, Apis florea F. and the giant honeybee, Apis dorsata F.) are among such pollinators. These honeybees make the natural pollinators of many locally grown crops $[9-12,19]$ and are bioresource of honey too. Apis florea makes small nest (comb) and gathers small quantity of honey as compared to Apis dorsata; the latter honeybee makes very large nest and gathers 8-10 times more honey than the former [1, 12, 19]. Furthermore, Apis florea and Apis dorsata have different pollination specializations and accordingly have their own distinct pollination importance too [10-12, 19]. Due to its indigenous nature, association of the giant honeybee with the local flora should be unparallel. However, detailed knowledge on this aspect for the crops grown in the semiarid environment of Northwest India is lacking. To gain knowledge about all these aspects, the present study was undertaken.

\section{Material and Methods}

This study was carried out at the main campus (in an area of about $5 \mathrm{~km}^{2}$ ) of CCS Haryana Agricultural University, Hisar (Haryana, India) from 1984 to 2012 where giant honeybee makes many nests every year. The following studies were carried out.

2.1. Phenology of Migration. To study the annual migratory pattern of giant honeybee, a survey was carried out at three years interval from 1984 to 2012 on the presence of colonies of giant honeybee along with its nests at the main campus (in an area of about $5 \mathrm{~km}^{2}$ ) of CCS Haryana Agricultural University, Hisar (Haryana, India). Observations were recorded in the last week of each month on the number of giant honeybee colonies present at various buildings and trees at the university campus. A record on the daily maximum and minimum temperatures was obtained from the Meteorological Observatory Laboratory of the University. From this survey data, the numbers of the new colonies of the giant honeybee immigrating/arriving in the beginning of honey flow season, established during the honey flow season, and swarm colonies originating during the breeding season and emigrating out of/leaving this region (as evidenced by the number of deserted combs) were ascertained. The data recorded was utilized to characterize the seasonal migration pattern of this honeybee.

2.2. Incidence of Diseases, Pests, Predators, and Enemies. A survey on the incidence of diseases, pests, predators, and 
enemies of this honeybee was also carried out. During the entire period of this study, observations were recorded on 60 colonies ( 30 colonies made nests on the artificial wooden planks specially designed and fabricated for manual manipulations and other 30 colonies made nest at a projection of the college building) which were within the approach for manipulations and/or recording observations on the brood condition and live bees. For the survey of honeybee diseases and pests, live colonies $(n=30$; nested on the artificial wooden supports) and the deserted combs ( $n=60 ; 30$ colonies nested on wooden supports and 30 on building projections) were examined for the presence/absence of their symptoms. Live colonies nesting on the wooden supports were individually lowered down gently without giving any jerk to the colony and water was sprayed gently over the bee blanket with the help of a one litter capacity hand sprayer to make the bees calm and unable to fly. Then, the bee curtain was removed with a fly flapper again gently to observe the brood condition in the colony. Presence or absence of the viral and bacterial brood diseases was confirmed on the basis of respective presence or absence of their symptoms in the brood $[20,21]$. The observations were initiated after a month of the settlement of the immigrated colonies and were repeated at 21 days interval till the desertion of the combs $(7 \times 30$ observations were made on the live colonies and 60 observations were made on the deserted combs). The deserted combs were examined only after the emigration of the colonies. Likewise, presence/absence of chalk/stone brood disease was ascertained on the basis of presence or absence of the symptoms of these diseases in the brood $[20,21]$. The adult bees lying on the floor below the colony nest were counted and collected occasionally, brought to the laboratory, and were examined for the presence of diseases [21]. These deaths took place for 30-35 days every year when night temperature in winter months fell below $20^{\circ} \mathrm{C}$. Every year, several such bees were dissected under light microscope in the laboratory and the color and phenotypic condition of their ventriculus and the water smear of the latter was examined for the presence/absence of nosemosis fungal disease [22].

For the survey of acarine disease, a sample of about 50 adult bees was drawn from each of the approachable colonies every year during early April (50 old colonies +50 swarm colonies) using Sihag Bee Sampler [23]. The sampled bees were washed in the soap water, sieved through the fine muslin cloth, and rewashed the supernatant in fresh water in a petri plate. The presence of any ectoparasitic mite in the sample was confirmed under the light microscope. Observations on the wax moth infestation were recorded by examining the upper part of the comb just with naked eyes. The wax moth infestation could become visible even from the surface of the colonies when white peg-like structures of wax moth cocoon appeared on the upper exposed honey part of the comb [17]. Likewise the wasp and bird predators and other enemies (ants, spiders, and vertebrates) preying upon or causing harm to this honeybee, were recorded on the foraging sites while recording observations on the foraging behavior of the bees and 20-25 times every week near the approachable two kinds of colonies.
2.3. Crop Hosts. A record of different crop plants visited by the foragers of the giant honeybee (Apis dorsata F.) was maintained through the year round. To ascertain whether this honeybee acted as a pollinator or a nonpollinator of the flowers of a reference crops it visited, the foraging behavior of its visitors on that crop was studied following Sihag [11], Sihag and Shivrana [24], and Robinson [25]. While visiting the flowers of a crop plant, if the foragers of this honeybee worked from the top of the flower, such foragers virtually came in contact with the reproductive organs (anthers and stigma) of the flowers. These foragers gathered pollen in each foraging effort/visit and transferred it during the subsequent visits to the succeeding flowers. These foragers were characterized as pollinators of the reference crop. However, if the foragers of this honeybee worked from the side of the flower to steal nectar only and did not come in contact with the reproductive organs of the flower, then this bee was characterized as a nonpollinator (nectar thief) of the reference crop. Furthermore, on the basis of pollen and nectar presentation by the plant and collection by the foragers of this honeybee, the plants were characterized as pollen and or nectar sources [16]. The crops which are grown in several thousand hectares in this region were characterized as the "major crops," whereas those crops which are grown in a few hundred hectare were characterized as "minor crops." Likewise, if the population of the foragers of this honeybee during the peak foraging hours (between 1200 and $1400 \mathrm{~h}$ on winter flowering and $0800-1000 \mathrm{~h}$ on summer flowering crops) on the reference crop was $>1$ bee per $\mathrm{m}^{2}$, it was characterized as a "frequent" visitor and if it was $<1$ bee per $\mathrm{m}^{2}$, it was characterized as the "occasional" visitor of that crop [16]. On these grounds, the importance of this honeybee as pollinator of the crops of semiarid region of Northwestern India was determined.

\section{Results}

3.1. Phenology of Migration. The data in Table 1 reveal that the giant honeybee commenced its immigration to this region in October with the peak flowering on pigeon pea and continued in November too. These colonies stayed here till midMay. During these months, the colonies produced swarm colonies too and multiplied (the latter event was preceded by buildup and honey storage activities). The swarms did not migrate to the alternate seasonal nesting sites, but established new colonies in the area around (Table 1). The colonies initiated the emigration from this region in May, and only a few colonies stayed after June and none after July.

The migration schedule of this honeybee seemed to coincide with the availability of bee forage in this region. After a long floral dearth from mid-May to mid-September, bee forage in this region commences with the initiation of flowering on pigeon pea (Cajanus cajan) in September (Table 2). This is followed by flowering on toria (Brassica campestris) in October and then on edible leafy mustard (Brassica juncea), one of the two major crops of this region, in early December. Flowering on chick pea (Cicer arietinum), another major crop of this region, stretches from December to midFebruary, and, on other but minor crops, it staggers for about eight months; the last crops to bloom are berseem/clover 
TABLE 1: Annual migratory and colony decline patterns of the giant honeybee in semiarid environment of Northwest India.

\begin{tabular}{|c|c|c|c|c|c|c|c|c|c|c|c|c|}
\hline \multirow{2}{*}{ Year } & \multicolumn{12}{|c|}{ Number of colonies of giant honeybee in different months and years of observations } \\
\hline & Sep $^{*}$ & Oct & Nov & Dec & Jan & Feb & Mar & Apr & May & Jun $^{*}$ & $\mathrm{Jul}^{*}$ & Aug $^{*}$ \\
\hline $1984-85$ & $0^{*}$ & $41 a$ & $41+63 a=104$ & 104 & 104 & $104+43 b=147$ & $147+\mathbf{5 6 b}=203$ & 203 & 52 & $5^{*}$ & $0^{*}$ & $0^{*}$ \\
\hline $1987-88$ & $0^{*}$ & $39 a$ & $39+71 a=110$ & 110 & 110 & $110+\mathbf{4 8 b}=158$ & $158+\mathbf{5 1 b}=209$ & 209 & 46 & $3^{*}$ & $0^{*}$ & $0^{*}$ \\
\hline $1990-91$ & $0^{*}$ & $36 a$ & $36+65 a=101$ & 101 & 101 & $101+\mathbf{4 2 b}=143$ & $143+51 b=194$ & 194 & 49 & $5^{*}$ & $0^{*}$ & $0^{*}$ \\
\hline 1993-94 & $0^{*}$ & $32 a$ & $32+59 a=91$ & 91 & 91 & $91+\mathbf{3 8 b}=129$ & $129+47 b=176$ & 176 & 54 & $4^{*}$ & $0^{*}$ & $0^{*}$ \\
\hline 1996-97 & $0^{*}$ & $29 a$ & $29+53 a=82$ & 82 & 82 & $82+\mathbf{5 1} \mathbf{b}=133$ & $133+41 b=174$ & 174 & 41 & $3^{*}$ & $0^{*}$ & $0^{*}$ \\
\hline $1999-2000$ & $0^{*}$ & $33 a$ & $33+42 a=75$ & 75 & 75 & $75+46 b=121$ & $121+42 b=163$ & 163 & 53 & $2^{*}$ & $0^{*}$ & $0^{*}$ \\
\hline $2002-03$ & $0^{*}$ & $27 a$ & $27+41 a=68$ & 68 & 68 & $68+\mathbf{3 8 b}=106$ & $106+43 b=149$ & 149 & 38 & $4^{*}$ & $0^{*}$ & $0^{*}$ \\
\hline $2005-06$ & $0^{*}$ & $32 a$ & $32+31 a=63$ & 63 & 63 & $63+33 b=96$ & $96+37 b=133$ & 133 & 41 & $3^{*}$ & $0^{*}$ & $0^{*}$ \\
\hline 2008-09 & $0^{*}$ & $28 a$ & $28+30 a=58$ & 58 & 58 & $58+\mathbf{3 4 b}=92$ & $92+29 b=121$ & 121 & 19 & $1^{*}$ & $0^{*}$ & $0^{*}$ \\
\hline 2011-12 & $0^{*}$ & $23 a$ & $23+21 a=44$ & 44 & 44 & $44+2 \mathbf{1 b}=65$ & $65+17 b=82$ & 82 & 22 & $2^{*}$ & $0^{*}$ & $0^{*}$ \\
\hline
\end{tabular}

$\mathrm{a}=$ immigrated colonies; $\mathrm{b}=$ swarm colonies, italic font $=$ immigration period, bold font $=$ swarming period, and $*=$ dearth period.

TABLE 2: Crop hosts of the giant honeybee in the semiarid environment of Northwest India.

\begin{tabular}{|c|c|c|c|}
\hline Crop host & Flowering time & Source $(P, N)$ & $\mathrm{p} / \mathrm{nt}$ \\
\hline (1) Pigeon pea (Cajanus cajan (L.) Millsp.) & Sep-Oct & $\mathrm{P}, \mathrm{N}, 2$ & p3 \\
\hline (2) Toria (Brassica campestris L. var. toria) & Oct-Nov & $\mathrm{P}, \mathrm{N}, 2$ & p3 \\
\hline (3) Edible leafy mustard (Brassica juncea Czern. \& Coss) & Dec-Feb & $\mathrm{P}, \mathrm{N}, 1$ & p3 \\
\hline (4) Chinese cabbage (Brassica chinensis L. D.) & Dec-Feb & $\mathrm{P}, \mathrm{N}, 2$ & p3 \\
\hline (5) Rape (Brassica napus L.) & Dec-Feb & $\mathrm{P}, \mathrm{N}, 2$ & p3 \\
\hline (6) Cauliflower (Brassica oleracea L. var. botrytis) & Dec-Feb & $\mathrm{P}, \mathrm{N}, 2$ & p3 \\
\hline (7) Radish (Raphanus sativus L.) & Dec-Feb & $\mathrm{P}, \mathrm{N}, 2$ & p3 \\
\hline (8) Turnip (Brassica rapa L.) & Dec-Feb & $\mathrm{P}, \mathrm{N}, 2$ & p3 \\
\hline (9) Salad rocket (Eruca sativa Mill.) & Dec-Mar & $\mathrm{P}, \mathrm{N}, 2$ & p3 \\
\hline (10) Chick pea (Cicer arietinum L.) & Dec-Feb & $\mathrm{P}, \mathrm{N}, 1$ & p3 \\
\hline (11) Coriander (Coriandrum sativum L.) & Feb-Mar & $\mathrm{P}, 2$ & p3 \\
\hline (12) Fenugreek (Trigonella foenum-graecum L.) & Feb-Mar & $\mathrm{P}, \mathrm{N}, 2$ & $\mathrm{p} 4$ \\
\hline (13) Lemon (Citrus limon (L.) Burm. f.) & March & $\mathrm{P}, \mathrm{N}, 2$ & p3 \\
\hline (14) Kinnow (Citrus nobilis $\times$ Citrus deliciosa) & March & $\mathrm{P}, \mathrm{N}, 2$ & p3 \\
\hline (15) Peach (Prunus persica) (L.) Stokes & March & $\mathrm{P}, \mathrm{N}, 2$ & p3 \\
\hline (16) Onion (Allium cepa L.) & Mar-Apr & $\mathrm{P}, \mathrm{N}, 2$ & p3 \\
\hline (17) Lentil (Lens culinaris Medikus) & Mar-Apr & $\mathrm{P}, \mathrm{N}, 2$ & $\mathrm{p} 4$ \\
\hline (18) Sun flower (Helianthus annuus L.) & Mar-May & $\mathrm{P}, \mathrm{N}, 2$ & p3 \\
\hline (19) Berseem/clover (Trifolium alexandrinum L.) & Mar-May & $\mathrm{P}, \mathrm{N}, 2$ & p3 \\
\hline (20) Alfalfa (Medicago sativa L.) & Mar-Oct & $\mathrm{P}, \mathrm{N}, 2$ & nt 3 \\
\hline (21) Guava (Psidium guajava L.) & Apr-May & $\mathrm{P}, \mathrm{N}, 2$ & p3 \\
\hline (22) Bottle gourd (Lagenaria siceraria (Molina) Standl.) & Mar-Nov & $\mathrm{P}, \mathrm{N}, 2$ & $\mathrm{p} 4$ \\
\hline (23) Ribbed gourd (Luffa acutangula (L.) Roxb.) & Mar-Nov & $\mathrm{P}, \mathrm{N}, 2$ & $\mathrm{p} 4$ \\
\hline (24) Bath sponge (Luffa cylindrica L.) & Mar-Nov & $\mathrm{P}, \mathrm{N}, 2$ & $\mathrm{p} 4$ \\
\hline (25) Bitter gourd (Momordica charantia L.) & Mar-Nov & $\mathrm{P}, \mathrm{N}, 2$ & $\mathrm{p} 4$ \\
\hline (26) Apple gourd (Praecitrullus fistulosus (Stocks) Pangalo) & Mar-Nov & $\mathrm{P}, \mathrm{N}, 2$ & $\mathrm{p} 4$ \\
\hline (27) Muskmelon (Cucumis melo L.) & Mar-Nov & $\mathrm{P}, \mathrm{N}, 2$ & $\mathrm{p} 4$ \\
\hline (28) Watermelon (Citrullus lanatus var. lanatus (Thunb.)) & Mar-Nov & $\mathrm{P}, \mathrm{N}, 2$ & $\mathrm{p} 4$ \\
\hline (29) Summer squash (Cucurbita pepo L.) & Mar-Nov & $\mathrm{P}, \mathrm{N}, 2$ & $\mathrm{p} 4$ \\
\hline (30) Kheera (Cucumis sativus L.) & Mar-Nov & $\mathrm{P}, \mathrm{N}, 2$ & $\mathrm{p} 4$ \\
\hline (31) Pumpkin (Cucurbita moschata Duchesne ex Poir.) & Mar-Nov & $\mathrm{P}, \mathrm{N}, 2$ & $\mathrm{p} 4$ \\
\hline (32) Petha (Benincasa hispida (Thunb.) Cogn) & Mar-Nov & $\mathrm{P}, \mathrm{N}, 2$ & $\mathrm{p} 4$ \\
\hline
\end{tabular}

$\mathrm{P}=$ pollen source; $\mathrm{N}$ = nectar source; 1 : major crop of the region; 2: minor crop of the region; $\mathrm{p}$ : foragers acted as pollinators, nt: foragers acted as nectar thieves; 3 : frequent visitor; 4 : occasional visitor. 
TABLE 3: Ambient temperature and humidity regimes at Hisar (Haryana, India).

\begin{tabular}{|c|c|c|c|c|c|}
\hline \multirow{2}{*}{ Season* ${ }^{*}$} & \multirow{2}{*}{ Months } & \multicolumn{2}{|c|}{ Relative humidity (ranges) } & \multicolumn{2}{|c|}{ Temperature regimes (ranges) } \\
\hline & & Minimum (\%) & Maximum (\%) & Maximum $\left({ }^{\circ} \mathrm{C}\right)$ & Minimum $\left({ }^{\circ} \mathrm{C}\right)$ \\
\hline Winter & December to mid-February & $50-60$ & $80-90$ & 10 to 25 & -1 to 13 \\
\hline Spring & Mid February to March & $40-50$ & $60-70$ & 25 to 30 & 15 to 20 \\
\hline Early summer & April to mid-May & $20-30$ & $40-50$ & 30 to 44 & 25 to 28 \\
\hline Late summer & Mid May to June/early July & $15-20$ & $30-35$ & 44 to 48 & 28 to 30 \\
\hline Monsoon & Early July to September & $70-80$ & $>90$ & 25 to 38 & 20 to 25 \\
\hline Autumn & October-November & $40-50$ & $60-70$ & 25 to 32 & $15-18$ \\
\hline
\end{tabular}

${ }^{*}$ Modified from Sihag [15].

TABLE 4: Incidence of diseases, pests, predators, and enemies of giant honeybee (Apis dorsata) in semiarid environment of Northwest India.

\begin{tabular}{|c|c|c|c|c|c|c|}
\hline \multirow{2}{*}{$\begin{array}{l}\text { Diseases, pests, } \\
\text { predators, and } \\
\text { enemies }\end{array}$} & \multicolumn{6}{|c|}{ Description of the pathogen/pest/enemy } \\
\hline & Symptoms & $\begin{array}{c}\text { Causal organism } \\
\text { present/absent }\end{array}$ & $\begin{array}{c}\text { Month of incidence/ } \\
\text { infestation }\end{array}$ & $\begin{array}{c}\text { Percent of } \\
\text { colonies affected }\end{array}$ & $\begin{array}{l}\text { Kind of damage } \\
\text { to the colony }\end{array}$ & $\begin{array}{l}\text { Gravity of damage } \\
\text { to the colony }\end{array}$ \\
\hline Viral disease & Absent & Absent & - & - & - & - \\
\hline Bacterial disease & Absent & Absent & - & - & - & - \\
\hline Fungal disease & Absent & Absent & - & - & - & - \\
\hline Protozoan disease & Absent & Absent & - & - & - & - \\
\hline Acarine disease & $\begin{array}{c}\text { No specific } \\
\text { symptom was } \\
\text { seen }\end{array}$ & $\begin{array}{c}\text { Tropilaelaps clareae } \\
\text { waspresent }\end{array}$ & Dec-April & $\begin{array}{c}\text { About } 20 \% \text { of the } \\
\text { old colonies } \\
(n=24, \\
N=117) ; \text { none } \\
\text { of the swarm } \\
\text { colonies }\end{array}$ & Not sure & Not sure \\
\hline $\begin{array}{l}\text { Wax moth } \\
\text { infestation }\end{array}$ & $\begin{array}{l}\text { Several silken } \\
\text { tunnels in the } \\
\text { midrib of the } \\
\text { comb }\end{array}$ & $\begin{array}{c}\text { Galleria mellonella } \\
\text { was present }\end{array}$ & Feb-May & $\begin{array}{l}100 \% \text { of old } \\
\text { colonies; none of } \\
\text { swarm colonies }\end{array}$ & $\begin{array}{l}\text { Destroy and } \\
\text { devour combs }\end{array}$ & $\begin{array}{l}\text { Combs in badly } \\
\text { damaged state }\end{array}$ \\
\hline $\begin{array}{l}\text { Predatory } \\
\text { wasp(s)/birds }\end{array}$ & Not seen & Absent & - & - & - & - \\
\hline Other enemies & Not seen & Absent & - & - & - & - \\
\hline
\end{tabular}

-: incidence did not take place; $N=$ Total number of colonies observed; $n=$ Number of colonies showing the presence of mites.

(Trifolium alexandrinum) and sunflower (Helianthus annuus) during March-May. From May to early/mid-July, this region witnesses a very high ambient temperature ranges $\left(43-48^{\circ} \mathrm{C}\right.$ or sometimes even more than this range) and from June to mid-/late September represents the period of floral dearth (Tables 2 and 3); only cucurbits and some other minor vegetable crops are in blooms during this period.

These patterns of ambient temperature, flowering on the crops and the migration of the giant honeybee colonies were repeated year after year, with slight deviations, perhaps caused by the ambient temperature regimes.

3.2. Decline in Colony Numbers. The most striking feature of this study was the continuous decline in the number of immigrating and swarm colonies of this honeybee in this region (Table 1). In the beginning of this study, in 1984, 104 colonies of the giant honeybee immigrated in the study area. This number remained more than 100 even in 1991. However, this number reached just 44 at the end of this study in 2012. Same was the case with the swarm colonies. The number of the latter colonies established in the study area was 99 from 1984 to 1987 . However, this number declined to merely 38 in 2012. The trend of the total colonies was also not different. Total colonies in April 1984 in the study area were 203 which lasted to just 82 in 2012 (Table 1). On all counts, over a period of 30 years, there was a 59.1 percent decrease in the number of the giant honeybee colonies in the study area of this region as the total colony number at the end of this survey was even less than half of the original figures.

3.3. Incidence of Diseases, Pests, Predators, and Enemies. In semiarid environment of Northwest India, the giant honeybee was free from any viral, bacterial, fungal, and protozoan disease (Table 4). During the entire period of this study, no dead larvae were observed in the brood of 30 colonies nesting on wooden planks/frames and also in the deserted combs of 60 colonies. Therefore, symptoms of sac brood or foul brood diseases, as found in Apis mellifera, were absent in the giant honeybee. This excluded the presence of any viral or bacterial brood disease in the giant honeybee. 
Likewise, there were no symptoms of chalk or stone brood diseases in the brood of 60 colonies. In the absence of any larval mortality and symptoms, the presence of any viral, bacterial, or fungal disease in brood of the giant honeybee was completely excluded, and no other tests were necessitated. Likewise, no live bees trembling or crawling on the floor below the colony nests were ever seen. During this period, symptoms of bee dysentery were also not present. No black excreta of bees were ever present on the floor below the colony nest. However, some adult bee deaths did take place during the extreme winters (range 80-150 per day, mean \pm s.d. = $53.3 \pm 54.6, n=146$ ), which continued for 5-10 days every year when night temperature fell below $10^{\circ} \mathrm{C}$. Before and after these chilling nights, when night temperature remained between $10-15^{\circ} \mathrm{C}$, for 15 to 20 days, these bee deaths were small in number (range $10-50$ per day, mean \pm s.d. $=14.3 \pm 3.6$, $n=120$ ). In the nights with temperature above $15^{\circ} \mathrm{C}$ the bee deaths decreased to very small numbers (range $=5-10$ per day, mean \pm s.d. $=6.1 \pm 2.4, n=120$ ), and bee deaths were rare in the nights with temperature $>20^{\circ} \mathrm{C}$. An aqueous smear of ventriculus of the bees sampled from the dead pools examined under light microscope did not confirm the presence of spores of Nosema fungus. These deaths seemed to be caused by the super cooling of the bees on the outer curtain of the bee blanket and not at all due to any of the major diseases mentioned above.

This honeybee was found to be infested with two pests, namely, an ectoparasitic mite (Tropilaelaps clareae) and a wax moth (Galleria mellonella). About 20 percent of the old colonies (24 out of 117 colonies) were infested with ectoparasitic mite. Though the intensity of mite infestation in the brood could not be ascertained, the number of phoretic mites remained low and variable (range $=0-8$, mean + s.d. $=$ $2.5+3.8, n=50$ ). On the other hand, invariably, all the old colonies were found to be infested with the wax moth pest. Surprisingly, the swarm colonies were free from these pests. The wax moth infestation could become visible even from the surface of the colonies when white peg-like structures of wax moth cocoon appeared on the upper exposed honey part of the comb. However, during the entire study period, this honeybee was not found to be attacked by any predatory wasp or the bird on the nesting or the foraging site. Likewise, other enemies like ants, spiders, toads, and other vertebrates were also not conspicuous to register their presence.

None of the examined colony was found to show the presence of pollen or honey in its deserted comb. This indicates that all the stored foods were completely exhausted before deserting the comb. In none of the old colonies $(n=100$; 10 colonies each year $\times 10$ years) and only in 3 percent of the swarm colonies examined ( $n=100 ; 10$ colonies each year $\times$ 10 years), the deserted combs had sealed and/or unsealed (larvae/eggs) brood. This indicated that under the gravity of emigration stimulus generated by the adverse conditions, the affected colonies were forced even to surpass their brood rearing instinct by deserting the live brood in the comb.

3.4. Factors Inducing Migration and Decline in Colony Numbers. The diseases did not seem to stimulate the colonies of the giant honeybee for seasonal migrations as these were absent in the examined colonies in the semiarid environment of Northwestern region of India. However, as stated above, the colonies of the giant honeybee were found to be infested with two pests, namely, an ectoparasitic mite (Tropilaelaps clareae) and a wax moth (Galleria mellonella). About 20 percent of the old colonies were infested with ectoparasitic mite and invariably all the old colonies with the wax moth pest. These two pests can induce absconding in this honeybee. However, these did not seem to cause emigration of the infested colonies. This is because, none of the swarm colonies had these pests and still these too emigrated. The absence of phoretic mites in the swarm colonies may be due to their excessive low number in the samples which could not be detected by the method used in this study. Some other factor(s) seemed to induce emigration of the colonies from this region. From May to early July, this region witnesses a very high temperature (in the range of $43-48^{\circ} \mathrm{C}$ ) (Table 3 ) and June to mid-September represents a period of a floral dearth (Table 2). Then, emigration in the giant honeybee seems to be induced by the nonavailability of the bee forage (witnessed by a floral dearth) either resulting due to a drought condition caused by high temperature and low humidity or due to the absence of any crop or other plant in flowering stage [16] (Tables 2 and 3 ).

3.5. Crop Hosts. The giant honeybee was found to visit the flowers of more than 30 crops for pollen and/or nectar (Table 2). Of the 32 crops mentioned, only two are major crops of this region which are grown in several thousand hectares; all the other crops are minor crops as these are grown only in a few hundred hectares. Coriander (Coriandrum sativum) crop is a pollen source for this honeybee; all other crops are source of both pollen and nectar. On fenugreek (Trigonella foenum-graecum), lentil (Lens culinaris), and all the cucurbit crops, this honeybee is an occasional visitor; on all other crops mentioned here, this honeybee is a frequent visitor. On alfalfa (Medicago sativa L.) some of the foragers of this honeybee were the side workers/nectar thieves and did not act as pollinators. On all other crops mentioned here, the foragers of this honeybee invariably were the top workers and transferred pollen in each foraging attempt thus always acted as pollinators. These observations indicate that the giant honeybee is an important pollinator of some 20 crops of this region (Table 2).

\section{Discussion}

In the Northwestern region of India, the colonies of the giant honeybee arrived in the postrainy season (OctoberNovember), stayed there in winter (December-midFebruary), spring (mid-February-March), and early summer (April-mid-May) seasons, and left that place at the onset of extreme summer (mid-May). This migration schedule of the giant honeybee was in contrast to that shown in South India and Sri Lanka. In the latter locations, the colonies of this honeybee arrive to the mountains at the beginning of dry season (October-December) and to the plains at the beginning of the rainy season (May-July). Frequency and the timing of migration depended on the 
climatic rhythm of the region [1-3]. The differences in the migration schedule seemed to be due to differences in the local weather and climatic conditions. Northwestern region of India represented semiarid environmental conditions whereas South India (Bangalore) and Sri Lanka, both lie in the tropical region.

The migration schedule of the giant honeybee seemed to be influenced by two major factors, namely, (i) incidence of diseases, pests, predators, and other enemies and (ii) ambient temperature coupled with availability of bee forage. No diseases and enemies of the giant honeybee were observed in the Northwestern region of India. Two pests were prevalent in this honeybee. Wax moth (Galleria mellonella) was found to be a serious pest of this honeybee in this region [17], but this pest does not seem to be the causal factor to induce annual migration of the colonies, as this pest may cause absconding in honeybees but not the migration. Ectoparasitic mite, Tropilaelaps clareae, was found to infest about 20 percent of the colonies of this honeybee in Northwestern part of India. This mite was first reported on the giant honeybee in Philippines [26]. Though this mite has distinct parasitic characters and mode of life [27], yet the losses due to T. clareae in the giant honeybee seemed to be less than its secondary host, Apis mellifera. This is because the giant honeybee has a special defensive behavior against this mite. This honeybee captures and bites this mite. The dead mite collected from the giant honeybee experiments showed injuries which were apparently caused by the biting of $A$. dorsata bees [28]. Then, this mite too does not seem to be the causal factor of annual migration of the colonies of the giant honeybee.

Though the green bee-eater (Merops orientalis orientalis Latham) and the yellow-banded brown wasp (Vespa orientalis L.) are two serious predators of Apis mellifera in this region [20, 29-32], these were never seen near the colonies or on the foraging site of giant honeybee even during the inclement weather conditions. At least, 60 of these colonies remained under the daily observations of the author during their entire stay here. Likewise, other enemies of honeybees (mainly ants, beetles, and vertebrates) were also absent in this region. Therefore, pests, predators, and enemies were also not the causal factors to induce migration in the giant honeybee colonies.

The nonavailability of bee forage supplemented by ambient temperature condition should be the cause to induce seasonal migration of the colonies of the giant honeybee. This is because ambient temperature in this region becomes favorable with the commencement of monsoon in mid-July that staggers up to late September. However, the colonies immigrate in this region only in October/November when pigeon pea and/or toria is/are in blooms. This indicates that ambient temperature alone is not the causal factor inducing immigration in this honeybee. Had this been there, the colonies of this honeybee could have arrived here right in the month of July, but that did not happen. Therefore, availability of the bee forage is the sole factor inducing immigration in this honeybee. Likewise, emigration of colonies from this region is scheduled with the simultaneous incidence of high temperature and floral dearth. The giant honeybee is well adapted to high temperatures; the bees ventilate the nest and loosen the curtain to cool down the nest at high temperatures. Therefore, high temperature is not the direct factor stimulating migration in this honeybee. However, it induces migration of bees indirectly by influencing the flowers and drying of the nectar in the flowers. Next, the drought occurs and the flowers and the plants themselves dry. This seemed to make the living of this honeybee in this region very difficult, if not impossible. Then, emigration in the giant honeybee seems to be induced by the nonavailability of bee forage (witnessed by a floral dearth) either resulting due to a drought condition caused by high temperature and low humidity (Table 3 ) or due to the absence of any crop in flowering stage (Table 2).

In Northwestern region of India, the giant honeybee makes nests on the tall trees like Dalbergia sissoo Roxb. and Eucalyptus hybrida L. and the building projections [19]. While the number of the building sites remains unaltered or may increase in the coming years, the number of nesting trees on the campus has declined drastically (unpublished observations). This has led to the tremendous decline in the number of immigrating and swarm colonies at the study site. Apis cerana is not indigenous to this region and beekeeping with Apis mellifera is still in an incipient stage; many crops of this region solely rely for their pollination on the wild honeybees Apis florea and Apis dorsata. Furthermore, viewing the importance of bees in the conservation of floral diversity [33], persistent decline in the number of giant honeybee colonies at the CCSHAU campus over the years is a serious loss of pollination service to the ecosystem. This should ring the alarm bell for the honeybee scientists, crop growers, and plant conservationists to restore the nesting trees of this honeybee in this region.

The migration schedule of the giant honeybee in the semiarid environment of Northwest India was found to be programmed on a set annual pattern. During its stay in this region, this honeybee visited more than 30 locally grown crops and acted as an important pollinator of at least 20 of these crops (Table 2). In earlier studies too, this honeybee was identified as an excellent honey producer and an important wild pollinator of crop and other plants [8-11]. But, in the semiarid environment of Northwest India, Apis cerana is not indigenous and managed pollination with Apis mellifera is not yet practiced. In the absence of these pollinators, the crop growers have to rely on the wild pollinators of crops. This is the reason that this honeybee in Northwest India as pollinator of crops gains much greater importance than any pollinators and at any other place. Therefore, in recent years when there is great emphasis on increase in the crop production, conservation of this honeybee has gained much greater agroecological importance than any other times, especially in the light of its declining number of colonies in this region.

\section{Conclusion}

The giant honeybee was found to immigrate in this region in October/November when ambient temperature became favorable and flowering commenced on pigeon pea. The 
immigrated colonies were involved in buildup and storage activities and multiplied and stayed here till April and emigrated from this region in May/June when dearth period coupled with high ambient temperature leading to a drought condition commenced. This migration cycle was repeated year after year. However, the number of immigrating colonies declined markedly over the years. During its stay here, this honeybee acted as a pollinator of more than 30 crop plants. This honeybee was found to be infested with two pests, namely, an ectoparasitic mite (Tropilaelaps clareae) and a wax moth (Galleria mellonella); other enemies were not reported. The number of immigrating colonies over the years declined markedly.

The present study, which is in agreement with the observations of other researchers, provides interesting information about four important features of the giant honeybee in semiarid environment of Northwestern region of India. First, the foraging behavior of this honeybee qualifies it for an important pollinator of more than 30 crops of this region (Table 2). Therefore, methods of its domestication, conservation, and utilization as pollinator of crops must be devised. Second, the annual migratory pattern of this honeybee is well programmed with the ambient temperature conditions and the availability of bee forage which have set this phenomenon to be undertaken in the same months year after year (Tables 1,2 , and 3). This information can be used for the utilization of this honeybee for pollination of the local crops and honey production. Third, the colonies of the giant honeybee stay in this region as long as local crops are in blooms or until the dearth period commences. This information can be used for scheduling the honey and beeswax harvest timings from the colonies and/or deserted combs of this honeybee. Fourth, over the years, there was marked decline in the number of colonies of the giant honeybee in this region. This was due to the severe loss of its natural nesting sites (trees). Therefore, for the conservation of this honeybee in the regions of its migrations, conservation and restoration of the trees where this honeybee make nests must be carried out.

\section{Conflict of Interests}

There was no conflict of interests during the study and in the publication of this research.

\section{Acknowledgments}

The author is thankful to the succeeding Heads of the Department of Zoology, CCS HAU, Hisar, India, for the general facilities. He extends his thanks to all those who provided him with assistance in the field and laboratory work during the long course of this study, especially members of his field staff Jhokhu Lal Yadav, Jagmal Singh, Dalbir Singh, Sarwan Kumar, Budhi Raja, and J. P. Narain Chaturvedi. This study was carried out under the long-term projects " $\mathrm{C}(\mathrm{a})$ Zoo-2- Plan (Agri.)," C(a) Zoo-2- Non-Plan (Agri.)," and "B (IV)-NP (Agri.)," sponsored by the State Government of Haryana. Very useful comments and suggestions by the two anonymous reviewers on the earlier version of this paper are gratefully acknowledged.

\section{References}

[1] F. Ruttner, Biogeography and Taxonomy of Honeybees, Springer, Berlin, Germany, 1988.

[2] N. Koeniger and G. Koeniger, "Observations and experiments on migration and dance communication of Apis dorsata in Sri Lanka," Journal of Apicultural Research, vol. 19, pp. 21-34, 1980.

[3] G. Venkatesh and C. Chandrasekhara Reddy, "Rates of swarming and absconding in the giant honey bee, Apis dorsata F," Proceedings of the Indian Academy of Sciences (Animal Sciences), vol. 98, no. 6, pp. 425-430, 1989.

[4] J. Woyke, J. Wilde, and M. Wilde, "Swarming and migration of Apis dorsata and Apis laboriosa honey bees in India, Nepal and Bhutan," Journal of Apicultural Science, vol. 56, no. 1, pp. 81-91, 2012.

[5] J. B. Shrestha, C. K. Mandal, S. M. Shrestha, and F. Ahmad, "The trend of the giant honeybee, Apis dorsata Fabricius colony migration in Chitwan, Nepal," The Wildife, vol. 7, no. 10, pp. 1620, 2002.

[6] S. Pokhrel, "Climato-cyclic immigrations with declining populations of wild honeybee, Apis dorsata F. in Chitwan valley, Nepal," The Journal of Agriculture and Environment, vol. 11, no. 6, pp. 51-58, 2010.

[7] F. C. Dyer and T. D. Seeley, "Colony migration in the tropical honey bee Apis dorsata F. (Hymenoptera: Apidae)," Insectes Sociaux, vol. 41, no. 2, pp. 129-140, 1994.

[8] B. P. Oldroyd and S. Wongsiri, Asian Honey Bees: Biology, Conservation and Human Interactions, Harvard University Press, 2006.

[9] G. S. Mann and G. Singh, "Activity and abundance of pollinators of plums at Ludhiana (Punjab)," American Bee Journal, vol. 123, p. 595, 1983.

[10] R. C. Sihag, "Insect pollination increases seed production in cruciferous and umbelliferous crops," Journal of Apicultural Research, vol. 25, no. 2, pp. 121-126, 1986.

[11] R. C. Sihag, "Characterization of the pollinators of cultivated cruciferous and umbelliferous crops of sub-tropical Hisar (India)," Bee World, vol. 69, no. 4, pp. 153-158, 1988.

[12] R. C. Sihag, "Eco-biology of the giant honey bee (Apis dorsata F.) in semi-arid sub-tropical climates of India," in Asian Bees and Beekeeping: Progress of Research and Development, M. Matsuka, Ed., pp. 50-52, Oxford \& IBH, New Delhi, India, 2000.

[13] J. C. Biesmeijer, S. P. M. Roberts, M. Reemer et al., "Parallel declines in pollinators and insect-pollinated plants in Britain and the Netherlands," Science, vol. 313, no. 5785, pp. 351-354, 2006.

[14] S. G. Potts, J. C. Biesmeijer, C. Kremen, P. Neumann, O. Schweiger, and W. E. Kunin, "Global pollinator declines: trends, impacts and drivers," Trends in Ecology and Evolution, vol. 25, no. 6, pp. 345-353, 2010.

[15] R. C. Sihag, "Life cycle pattern, seasonal mortality, problem of parasitization and sex ratio pattern in alfalfa pollinating megachilid bees," Zeitschrift für Angewandte Entomologie, vol. 96, no. 1-5, pp. 368-379, 1983.

[16] R. C. Sihag, "Ecology of European honey bee (Apis mellifera L.) in semi-arid sub-tropical climates. 1. Melliferous flora and overseasoning of the colonies," Korean Journal of Apiculture, vol. 5, no. 1, pp. 31-43, 1990. 
[17] R. C. Sihag, "Problem of wax moth (Galleria mellonella L.) in the colonies of giant honeybee, Apis dorsata in Haryana," Indian Bee Journal, vol. 44, pp. 107-109, 1982.

[18] K. Aggarwal, "Incidence of Tropilaelaps clareae on three Apis species in Hisar (India)," in Africanized Honey Bees and Bee Mites, G. R. Needham, R. E. Page, M. Delfinado-Baker, and C. E. Bowman, Eds., pp. 396-403, Ellis Horwood, New York, NY, USA, 1988.

[19] R. C. Sihag, "Eco-biology of the little honeybee (Apis florea F.) in semi-arid sub-tropical climates of India," in Asian Bees and Beekeeping: Progress of Research and Development, M. Matsuka, Ed., pp. 46-49, Oxford \& IBH Publishing Company, Private Limited, New Delhi, India, 2000.

[20] R. C. Sihag, "Ecology of European honey bee (Apis mellifera L.) in semi-arid sub-tropical climates. 2. Seasonal incidence of diseases, pests, predators and enemies," Korean Journal of Apiculture, vol. 6, no. 1, pp. 16-26, 1991.

[21] R. A. Morse and K. Flottum, Eds., Honey Bee Pests, Predators and Diseases, Wicwas Press, 1998.

[22] I. Fries, M.-P. Chauzat, Y.-P. Chen et al., "Standard methods for Nosema research," Journal of Apicultural Research, vol. 52, no. 1, pp. 1-28, 2013.

[23] R. C. Sihag, "A simple apparatus for sampling honey bees from wild bee colonies," Bee World, vol. 68, no. 4, p. 179, 1987.

[24] R. C. Sihag and S. Shivrana, "Foraging behaviour and strategies of the flower visitors," in Pollination Biology: Basic and Applied Principles, R. C. Sihag, Ed., pp. 53-73, Rajendra Scientific Publishers, Hisar, India, 1997.

[25] W. S. Robinson, "Effects of apple cultivar on foraging behavior and pollen transfer by honey bees," Journal of the American Society for Horticultural Science, vol. 104, pp. 596-598, 1979.

[26] M. D. Delfinado and E. W. Baker, "Tropilaelaps, a new genus of mite from the Philippines (Laelapidae [s.lat.]: Acarina)," Fieldiana-Zoology, vol. 44, no. 7, pp. 53-56, 1961.

[27] R. C. Sihag and M. Singh, "The honey bee mite, Tropilaelaps clareae Delfinado \& Baker. 1. A mite with distinct ectoparasitic characters and mode of life," Indian Bee Journal, vol. 53, no. 1-4, pp. 56-67, 1991.

[28] N. Koeniger and N. Muzaffar, "Lifespan of the parasitic honeybee mite, Tropilaelaps clareae, on Apis cerana, dorsata and mellifera," Journal of Apicultural Research, vol. 27, no. 4, pp. 207221, 1988.

[29] R. C. Sihag, "The yellow banded brown wasp, Vespa orientalis. 1. A predator and colony robber of honey bee (Apis mellifera $\mathrm{L}$ ) in Haryana (India)," Korean Journal of Apiculture, vol. 7, no. 1, pp. 32-34, 1992.

[30] R. C. Sihag, "The yellow banded brown wasp, Vespa orientalis 2. Population density, bee capture efficiency and predation rate on honey bee (Apis mellifera L.)," Korean Journal of Apiculture, vol. 7, no. 1, pp. 35-38, 1992.

[31] R. C. Sihag, "The green bee-eater, Merops orientalis orientalis Latham. 1. Seasonal activity, population density, feeding capacity and bee capture efficiency in the apiary of honey bee, Apis mellifera L. in Haryana (India)," Korean Journal of Apiculture, vol. 8, no. 1, pp. 5-9, 1993.

[32] R. C. Sihag, "The green bee-eater, Merops orientalis orientalis Latham. 2. Quantitative losses caused to the colonies of honey bee, Apis mellifera L. in Haryana (India)," Korean Journal of Apiculture, vol. 8, no. 1, pp. 10-13, 1993.

[33] R. C. Sihag, "Bee diversity for floral diversity," Nature Science, vol. 6, no. 4, pp. 273-278, 2013. 

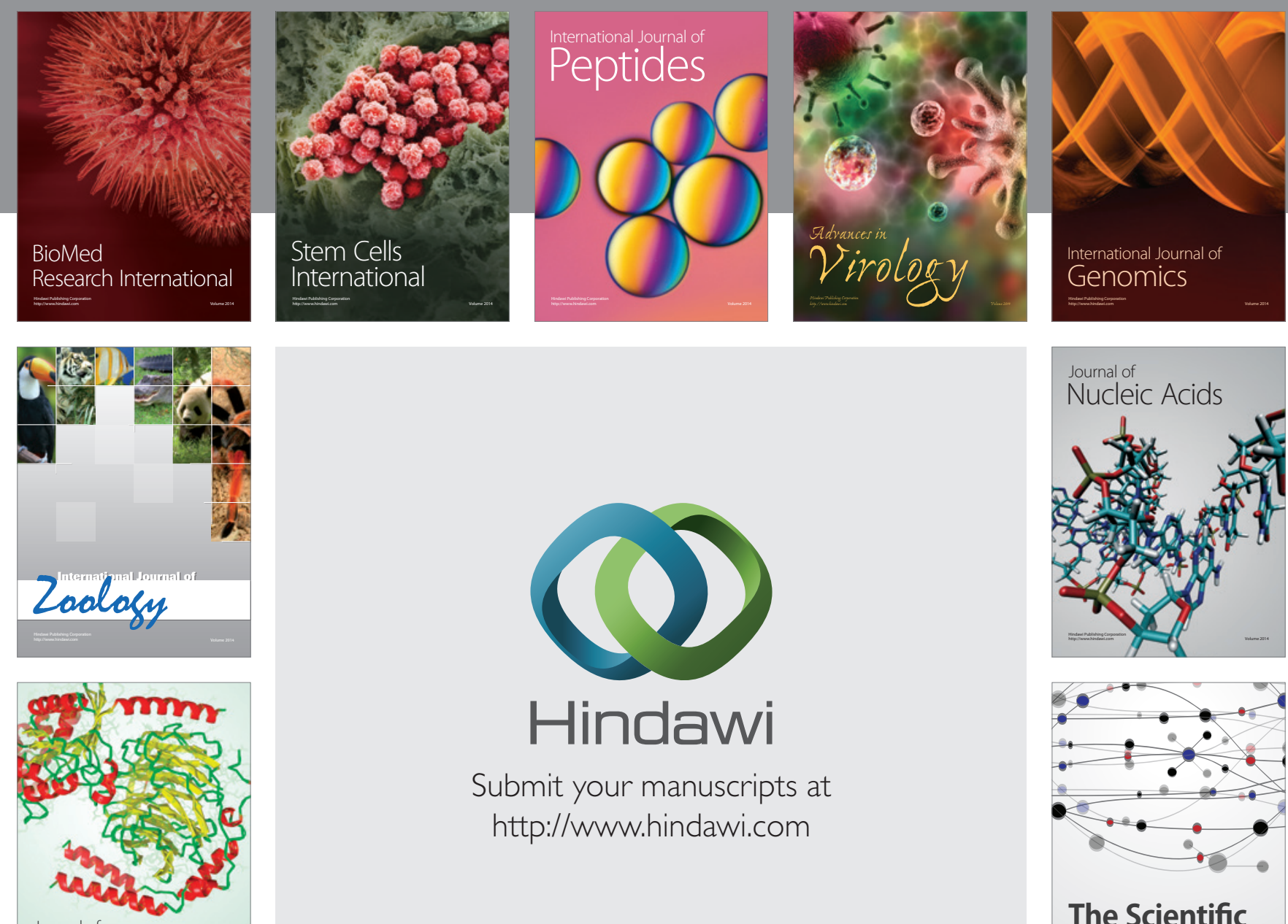

Submit your manuscripts at

http://www.hindawi.com

Journal of
Signal Transduction
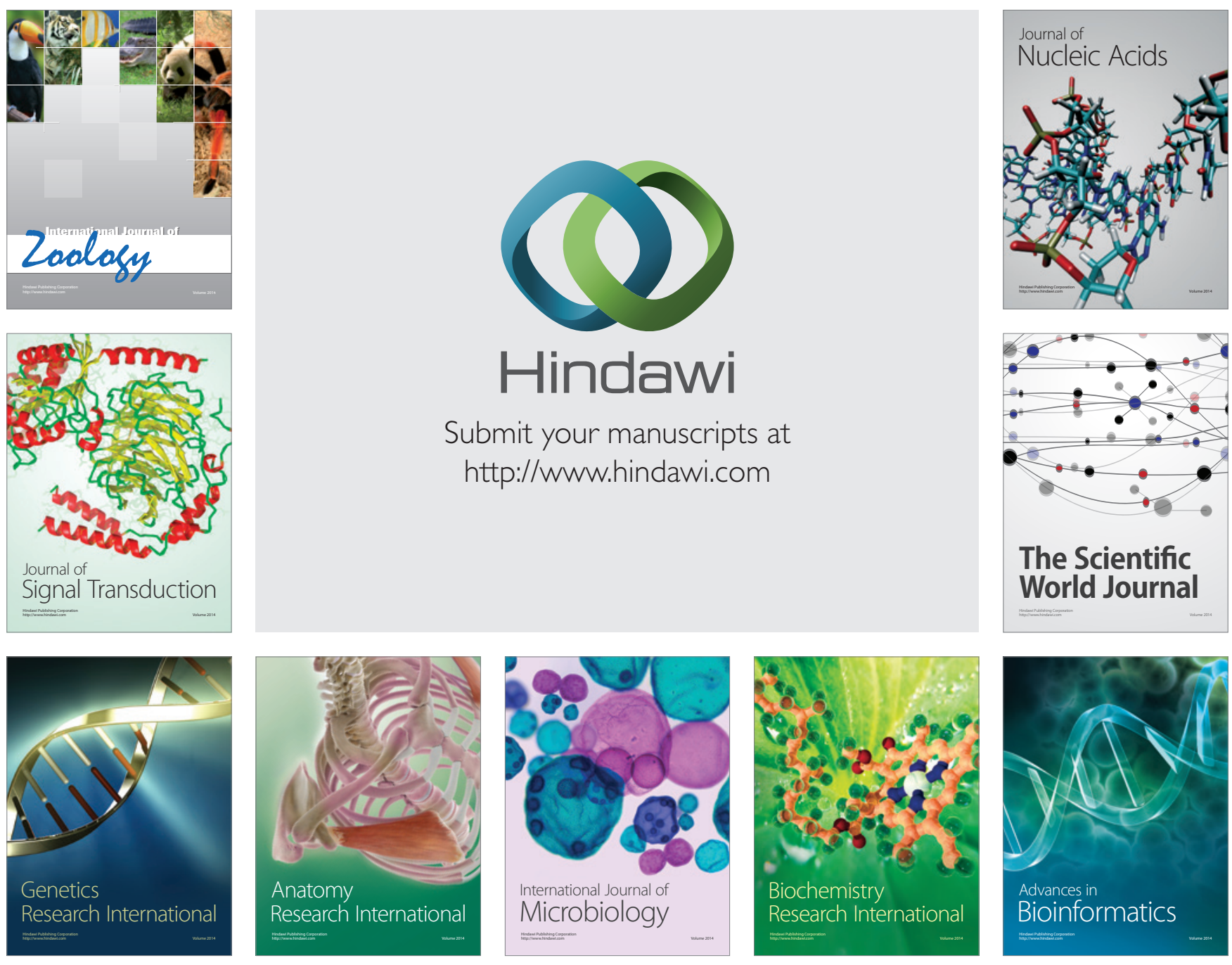

The Scientific World Journal
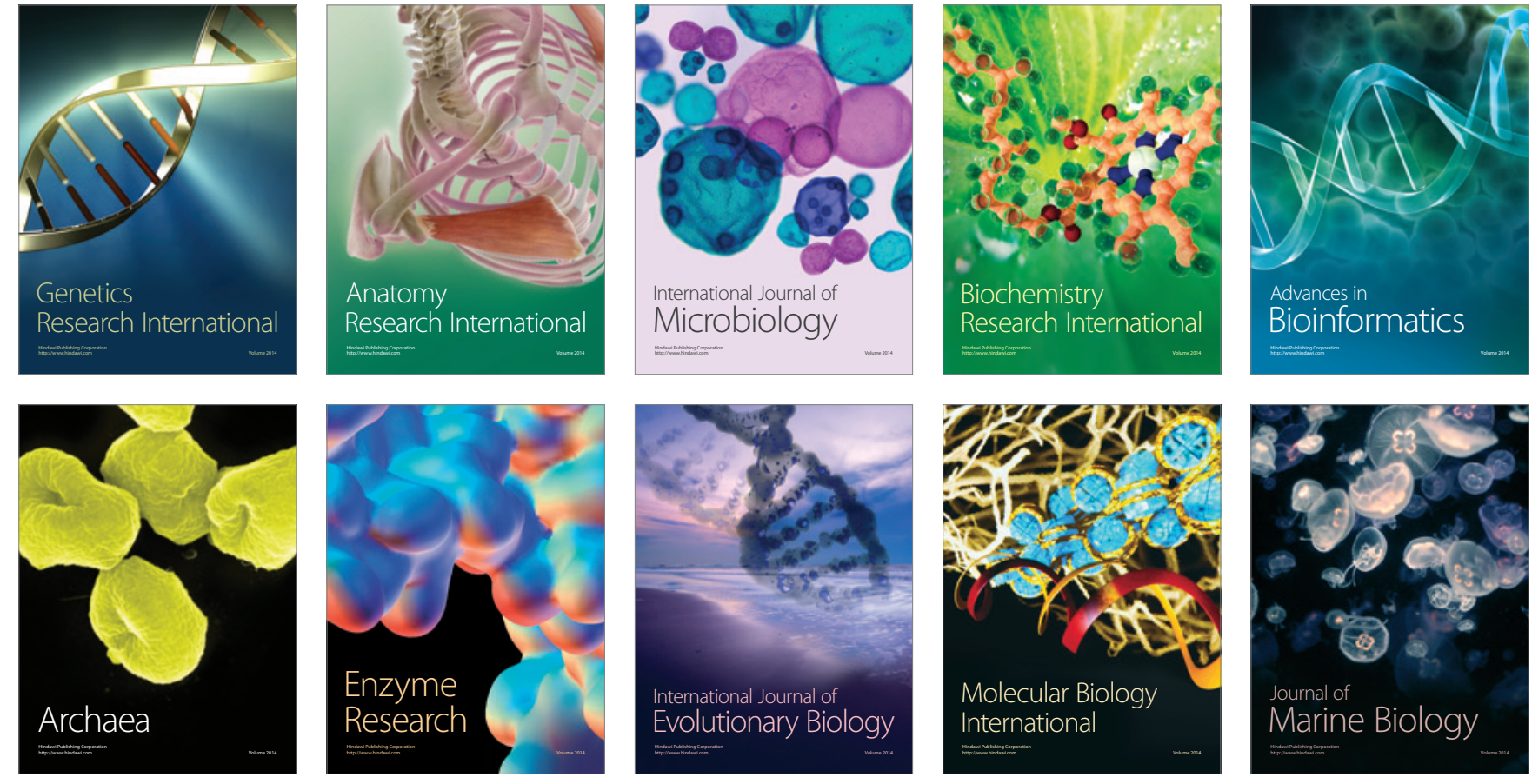